5 Davis, S. N., Amer.J. Sci., 262, 870 (1964).

6 Davis, S. N., Trans. Amer. Geophys. Union, 50, 141 (1969).

7 Keller, H. M., J. Hydrol. (NZ), 9, 133 (1970).

8 Gibbs, R. J., Geochim. Cosmochim. Acta, 36, 1061 (1972).

Cleaves, E. T., Godfrey, A. E., and Bricker, O. P., Geol. Soc. Amer. Bull., 81, 3015 (1970).

10 Johnson, N. M., Likens, G. E., Bormann, F. H., Fisher, D. W., and Pierce, R. S., Water Resource Res., 5, 1353 (1969).

11 Edwards, A. M. C., J. Hydrol., 18, 219 (1973).

12 Harder, H., Geochim. Cosmochim. Acta, 29, 429 (1965).

13 Mortimer, C. H., Limnol. Oceanogr., 16, 387 (1971).

${ }^{14}$ Kato, K., Geochem. J., 3, 87 (1969).

15 Kobayashi, J., in Chemical Environment in the Aquatic Habitat (edit. by Golterman, H. L., and Clymo, R. S.), 41 (NorthHolland, Amsterdam, 1967).

16 Gessner, F., Int. Revue Ges. Hydrobiol., 45, 339 (1960).

17 Jones, L. H. P., and Handreck, K. A., Nature, 198, 852 (1963).

18 Beckwith, R. S., and Reeve, R., Austral. J. Soil Res., 2, 33 (1964).

\section{Grass Roots at the Base of the Neogene}

THE history of life on Earth seems to have been punctuated by fairly swift changes in ecosystems, brought about initially by tectonic or cataclysmic events. The flora, being at the base of the food chain, would have a secondary effect on faunal evolution when undergoing even slight modifications. Such an instance may be found at the end of the Mesozoic, when the oncoming angiosperms must have greatly modified faunal ecosystems on the land. But it would be incorrect to assume that these changes had no relevance to seafloor communities, especially with regard to the appearance of grasses.

The Graminae, although appearing in the Late Cretaceous, did not become abundant until early Neogene ${ }^{1}$. This group must have played a fundamental role in the shaping of Cainozoic ecosystems by providing a vast ground level food supply capable of being continuously cropped by herds of mammals, whilst also providing niches for many smaller organisms. It must also have modified the geomorphology by stabilization of the soil surface. The Marram grass Ammophila is a present day example, where stabilization of coastal dunes has enabled the establishment of complex ecosystems on formerly barren sands. Similar effects follow the appearance of marine grasses such as Thalassia in backreef communities in the West Indies ${ }^{2}$. It follows that remarkable changes must have occurred after the initial colonization of the seafloor by the Graminae. Backreef and inshore sediments would have been stabilized, accompanied by an accumulation of silt and mud-sized particles, an increase in the organic content of sediments and thus of deposit feeding organisms. Marine grasses would also have provided new sources of food for the macrofauna and microfauna and new means of dispersal for benthonic and phytal organisms, the latter perhaps resulting in a decreasing chance of isolation and speciation.

Unfortunately, the date of the appearance of marine grasses is not traceable by palynology because they produce pollen without exine, and so are not fossilized ${ }^{1}$. Their former presence can nevertheless be deduced by sedimentology and palaeontology. Sediments from these meadows are characterized by a bimodal distribution of grain size, having abundant trapped silt together with much coarse biogenic material, especially gastropods, serpulids, ostracods and foraminifera. My analysis of foraminifera living on seagrass from the Caribbean $^{3}$ has shown that they consist largely of different species to those dwelling on the sediment and are therefore useful as palaeoecological indicators. Examination of the published fossil record suggests that this seagrass association occurred for the first time in the early Miocene Alum Bluff stage of Florida, the microfauna of which has been described by Puri $^{4,5}$. It was also at this time that the typically phytal foraminifera Sorites, Amphisorus and Marginopora first appeared, becoming widespread throughout the tropics. On the debit side, the Miocene witnessed the extinction of the larger orbitoid and nummulitid foraminifera. This event may also have been precipitated by the appearance of seagrass, for they were probably adapted to the less stable sediments of Palaeogene reefal areas.

It therefore seems credible that the changes from Palaeogene to Neogene benthonic biofacies can be partly attributed to the effects that encroaching marine grasses must have had on the ecology.

I thank Professor T. Barnard and the Geology Department of University College, London, for help and advice, the Royal Navy for logistic support and the Natural Environment Research Council for financial support.

\section{D. BRASIER}

Department of Palaeontology,

Institute of Geological Sciences,

Ring Road, Halton,

Leeds LS15 8TQ

Received April 19, 1973.

1 Tschudy, R. H., and Scott, R. A., Aspects of Palynology (Wiley, London, 1969).

2 Scoffin, T., J. Sediment. Petrol, 40, 249 (1970).

3 Brasier, M. D., thesis, Univ. London (1972).

${ }^{4}$ Puri, H. S., Bull. Florida Geol. Surv., 36 (1953).

${ }_{5}^{5}$ Puri, H. S., J. Palaeont. Soc. India, 1, 153 (1956).

\section{BIOLOGICAL SCIENCES}

\section{Synthesis of a Matrix-supported Enzyme in Non-aqueous Conditions}

IN recent years the chemical and physical properties of matrix-supported enzymes have received considerable attention in the chemical literature ${ }^{1,2}$. The discovery that biologically active compounds can be fixed artificially to insoluble polymeric supports has generated an interest in these materials which is manifest in their wide applicability to the study of complex biological systems. This is so because, in general, the immobilization of active proteins has been shown to produce several significant chemical and physical changes in the protein relative to its native-state counterpart. For example, certain enzymes, which in an isolated extracellular environment exhibit relatively low thermal stability, can be materially stabilized by attachment to an inert polymeric support. Furthermore, chemical properties, which are manifest in the mechanism of action, can be altered significantly by the technique, for example reaction kinetics and substrate specificity.

Applied research ranges from the study of matricized enzymes as in vitro models for complex in vivo systems to, for example, their more practical use in continuous assay systems for glucose, urea and anticholinesterase compounds ${ }^{3}$. The uses of matrix-supported enzymes in the continuous resolution of racemic mixtures and continuous isomerizations and degradations of saccharides have become important industrial processes ${ }^{4}$.

In general, four basic procedures are used for preparing immobilized enzymes: (1) adsorption on synthetic resins ; (2) entrapment in gel lattices; (3) covalent binding through nucleophilic groups of the protein with electrophilic functional groups on inert polymers, and (4) covalent crosslinking with certain bifunctional reagents. Moreover, most recent research dealing with the synthesis of insolubilized enzymes has emphasized procedures which effect protein attachment to the support through covalent bonds. Typically, such synthetic routes as azide displacement, diazo coupling, and binding through cyclic imidocarbonates are used $^{2,5,6}$. Invariably though, the choice of activation procedure for a given polymeric support has been made so as to be consistent with covalent bond formation in aqueous 